\title{
A BUDAPESTI BÉRLAKÁSSZEKTOR PRIVATIZÁCIÓJÁNAK TÁRSADALMI- És VÁROSSZERKEZETI HATÁSAI
}

\author{
(Spatial aspects of the privatization of state housing in Budapest)
}

\section{KOVÁCS ZOLTÁN}

\section{Bevezetés}

A kelet-európai újszülött demokráciák közös jellemvonása a gazdasági élet eltérổ ütemú, de folyamatosan zajló átalakítása, mely az államnak a gazdasági élet különbözô területeirôl történố fokozatos visszavonulásában, a korábban állami tulajdonban levố javak teljes vagy részleges privatizációjában nyilvánul meg. A termeló szféra tulajdonviszonyainak átalakítása mellett érthetỡen nagy hangsúlyt kap a lakás- és ingatlanszektor részben már megkezdett privatizációja, az ország évi költségvetésének többszörösét kitevố állami bérlakásszektor sorsa.

A tanulmány célja, hogy rövid áttekintést adjon a szociális lakásgazdálkodás II. világháborút követố fejlổdéséról ${ }^{1}$, rámutatva a szocialista idổszak lakáspolitikájának legszembetûnôbb ellentmondásaira és a privatizáció várható városföldrajzi következményeire.

\section{A városfejlödés nagy korszakai és az állami bérlakásszektor kialakulása Budapesten}

A lakásépítkezések ütemét, valamint a város fizikai növekedését tekintve három nagy korszakot különböztethetünk meg Budapesten. A városnövekedés elsố dinamikus szakasza (,,városrobbanás"') a 19. század utolsó évtizedeire tehetô, amikor viharos népességnövekedés és a nyomában járó nagyarányú lakás- és közmưépítkezés jellemezte a város fejlổését ( $I$. ábra). Az ekkor épített lakások jelentős hányada a virágzó telek- és ingatlanspekuláció jóvoltából múszakilag alacsony színvonalú volt, sokszor nélkülözve a kor követelményeinek megfeleló komfortot. A századfordulót követốen az általános recesszió eredményeként mélypontra esett vissza az építkezési ütem, ami azután az I. világháborút megelốzổ néhány évben ismét a korábbi szintre emelkedett.

A város, és ezen belül a lakásállomány, fejlơdésének második nagy szakaszát a két világháború közötti idôszakkal azonosíthatjuk, amikor a fớváros növekedése az országos demográfiai folyamatokkal összhangban lelassult, $\mathrm{s}$ térbeli terjeszkedésének súlypontja elóbb a külsổ kerületekbe, majd az 1930-as évektól kezdve az agglomerációra tevổött át. Budapest fejlődésének harmadik nagy periódusát a II. világháborút követôen számíthatjuk. Ez a korszak a romok eltakarításával vette kezdetét, majd a 70-es évek soha nem látott méretư paneles építkezésein át napjaink lakáspiaci recessziójáig húzódik. 

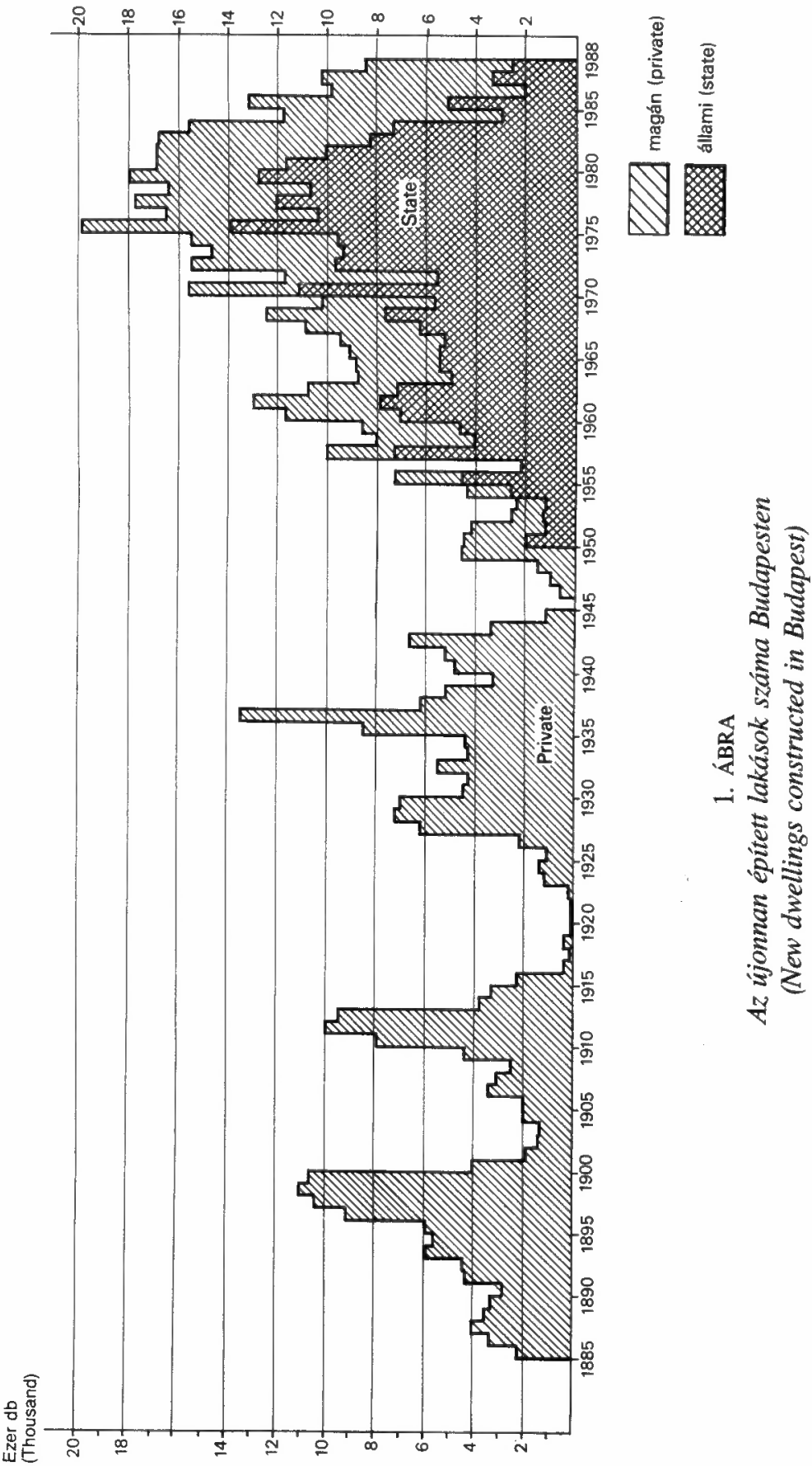
Kovács Zoltán : A budapesti bérlakásszektor privatizációjának társadalmi- és városszerkezeti hatásai (Spatial aspects of the privatization of state housing in Budapest)

Tér és Társadalom 6. évf. 1992/3-4. 55-73. p.

TÉT 1992-3-4

A budapesti bérlakásszektor privatizációjának

57

A II. világháborút megelởổen az állami bérlakásszektor a szó mai értelmében nagyon fejletlen volt. Voltak ugyan nagy állami vállalatok (pl. MÁV, BSZKRT.), melyek saját dolgozóik számára kedvezményes szolgálati lakásokat tartottak fenn, de a bérlakások döntố hányada magánkézben volt, s a lakbéreket is elsôsorban a piac határozta meg. A II. világháború befejezését követổen az új rendszer egyik legfontosabb tennivalói között szerepelt a korábbi lakásviszonyok átalakítása, s ezen belül a társadalmi szegregáció legfớbb okának tekintett tổkés bérlakásszektor megszüntetése. A gyors kisajátítások révén az állam vált - legalábbis a nagyobb városokban - az elsố számú ingatlantulajdonossá. Az új lakáspolitika, amely ingyenes lakáshozjutásban és jelképes lakbérekben öltött testet, az új rendszer legfóbb szociálpolitikai célkitứzését, jelesül a társadalmi homogenizációt, hivatott szolgálni.

Ennek tükrében érdemes megfigyelni, hogyan alakult az állam részesedése a budapesti lakásállományon belül (1. táblázat). Pontos adatok elốször csupán 1950-re állnak rendelkezésünkre, amikor Budapest lakásainak már közel 30\%-a volt állami kézben. Minthogy a háborús károk kijavításán túl új építkezésekre 1945-50 között központi forrásból lényegében alig került sor, a bérlakások számának hirtelen növekedése tisztán a kisajátításoknak volt köszönhetô. A kisajátítási hullám elsốsorban a belváros bérházait és a Budai-hegyvidék nagy értékử villáit érintette, s voltak kerületek ahol szinte a teljes épületállomány állami kézbe került (V., VI., VII. kerület). Az állami lakások aránya 1955-ig rohamosan növekedett, s megközelítette a 80\%-ot. Az állami szektor gyors terjeszkedése mellett a szocializmus korai szakaszát a lakásszegregáció háború elốtti méreteinek gyors ütemú mérséklởése, a korábbi elit lakónegyedek társadalmi felhígulási folyamata jellemezte.

\section{TÁBLÁZAT}

Az állami lakások aránya Budapesten, 1950-1990

(Proportion of state housing in Budapest between 1950-1990)

\begin{tabular}{cccc}
\hline 1. Év & $\begin{array}{c}\text { 2. Lakások száma } \\
\text { összesen (ezer) }\end{array}$ & $\begin{array}{c}\text { 3. Állami lakások } \\
\text { száma (ezer) }\end{array}$ & 4. Aránya (\%) \\
\hline 1950 & 410 & 140 & 29,9 \\
1951 & 470 & 176 & 37,4 \\
1952 & 473 & 358 & 75,7 \\
1953 & 475 & 367 & 77,2 \\
1954 & 477 & 372 & 77,9 \\
1955 & 480 & 376 & 78,3 \\
1960 & 536 & 384 & 71,6 \\
1970 & 619 & 389 & 62,8 \\
1980 & 709 & 408 & 57,5 \\
1990 & 789 & 410 & 51,9 \\
\hline
\end{tabular}

1. Year

2. Total No. of flats $(000)$

3. No. of state-owned flats $(000)$

4. Proportion of state-owned flats (\%) 
Kovács Zoltán : A budapesti bérlakásszektor privatizációjának társadalmi- és városszerkezeti hatásai

(Spatial aspects of the privatization of state housing in Budapest)

Tér és Társadalom 6. évf. 1992/3-4. 55-73. p.

A lakásépítkezések elhanyagolása és a háborút követôn nagyarányú népességbevándorlás krónikus lakáshiányhoz vezetett Budapesten, amit az orosz példa alapján részben a társbérleti rendszer meghonosításával, részben pedig az uralkodó osztály tagjainak erôszakos kitelepítésével véltek enyhíteni a hatóságok.

1956-ot követôen az államosítások beszüntetésével, valamint a magánerôs építkezések újbóli engedélyezésével a tanácsi lakások aránya a lakásállományon belül csökkenni kezdett. Nagyobb léptékú állami lakásberuházásra csak 1960-tól, a 15 éves lakásépítési terv elfogadása után, kerülhetett sor. A terv 1 millió lakás építését irányozta elô országosan az 1960-tól 1975-ig terjedó idốszakra, melybốl 250 ezret Budapesten kellett felépíteni. A terv teljesíthetôsége érdekében a városfejlesztés - és ez nem csak Budapestre érvényes - egyre inkább lakótelep-centrikus lett. 1975-re már négy hatalmas házgyár múködött Budapesten 15000 lakásos évi kapacitással ${ }^{3}$. Ez az erốsen koncentrált építỏipar az 1960-as évek végétốl panel lakótelepek egész sorát emelte a fốváros peremén, amely a város múlt század végi expanziójához hasonlatos gyors térbeli növekedést eredményezett. Az ekkor épült alvóvárosok kétszobás ,,egyenlakásaikkal” a szocializmus hatalmas olvasztótégelyét képezték. A fénykornak is tekinthetô 70-es évtizedben minden három épített lakásból kettố tanácsi volt. 1975-ben egy újabb optimista 15 éves lakásépítési terv került elfogadásra, amely a korábbinál is több (1,2 millió) lakás felépítését tứzte célul maga elé, ez azonban már nem valósulhatott meg. Az 1970-es évek végétôl, a 80-as évek elejétốl, az ismert gazdasági nehézségek következtében az állam visszavonulót fújt a lakásépítkezések terén is, s korábbi lakáspolitikájának átgondolására kényszerült. Többszörös lakbéremelés, a magánszektornak tett engedmények, a beruházások erốteljes visszafogása jelezték az állam szorult helyzetét. A központilag épített lakások száma viharos gyorsasággal csökkent, míg a magánépítkezések számában a válság ellenére növekedést figyelhettünk meg. Az újonnan épített lakások száma 1981 és 1986 között 50\%-kal csökkent, ami a folyamat drámai gyorsaságát jelzi. Elốzetes adatok szerint 1991-ben mindössze 100 darab állami lakás épült Budapesten az 1975-ös 15 000-rel szemben, s ez egyértelmüen jelzi a szocialista lakáspolitika csendes kimúlását. A privatizáció megindulása elốtt, az 1980-as évek elején, a bérlakások aránya már csupán 57\% volt, melyet az évtized végén végrehajtott elsô privatizációs hullám tovább csökkentett, egészen $50 \%$-ig.

\section{Szocialista lakáspolitika: csód, de miért?}

A budapesti lakásállomány az elmúlt negyven év során közel megkétszerezôdött, ami döntôen az állam építôtevékenységének volt köszönhetố, hiszen az állami bérlakások mellett a szövetkezeti és az OTP öröklakások is lényegében állami pénzen, központilag irányított és kivitelezett beruházások keretében valósultak meg. A látványos számbeli növekedés ellenére a háború utáni idốszak egyik legfontosabb jellemzóje az állandósult lakáshiány voḷt. Ebben az évtizedekig tartó krónikus lakáshiányban, valamint a szocialista lakáspolitika végsố bukásában számtalan ok játszott közre, gazdasági és társadalmi jellegủek egyaránt. A gazdasági oldalon az élre kívánkozik a központilag alacsonyan tartott lakbéreknek tulajdonítható pénzügyi csổ. Ugyan a szociális lakásellátás sehol a világon nem tartozik a jövedelmezổ vállalkozások közé, de a magyar 
Kovács Zoltán : A budapesti bérlakásszektor privatizációjának társadalmi- és városszerkezeti hatásai (Spatial aspects of the privatization of state housing in Budapest)

Tér és Társadalom 6. évf. 1992/3-4. 55-73. p.

TÉT 1992-3-4

A budapesti bérlakásszektor

59

bérlakás-szektor még arról a kevés bevételról is lemondott, amit egyébként minden nehézség nélkül, komfort és városrész szerint differenciált piaci lakbérekkel be tudott volna hajtani. Ez a lakbérpolitika, amely a lakbéreket igen alacsony szinten tartotta, a szocialista lakásgazdálkodás korai idôszakáig vezethetổ vissza, amikor az olcsó lakáshoz való jogot, legalábbis papíron, általánosnak ismerte el az állam. Ez egyúttal azt is jelentette, hogy a lakásprobléma megoldásának költségét az állam kiemelte a fizetésekból, s elviekben magára vállalta. Minthogy azonban az állam még a legnagyobb ütemú lakásépítkezések idején sem volt képes valamennyi arra rászorulónak lakást biztosítani, az eredeti elképzelés a gyakorlatban annyit jelentett, hogy az állam a népesség egy viszonylag szữk rétegének jelentôs támogatást juttatott, mégpedig olcsó bérư lakás formájában. Összehasonlító vizsgálatok tanúsága szerint az 1948-ban meghatározott lakbérek a II. világháború elớttinek mindössze egyharmadát tették ki, $\mathrm{s}$ az idốk folyamán ez a különbség az infláció következtében csak tovább nổtt. Jóllehet 1971-ben, az új gazdasági mechanizmus szellemében, $160 \%$-os központi lakbéremelést hajtottak végre, mindez nem jelentette a folyamat végét, $\mathrm{s}$ hatása csak idólegesnek bizonyult. Az állami lakásszektor deficitje 1982-ig növekedett, ámde akkor ismét közel duplájára nổttek a lakbérek ${ }^{4}$. Az említett lakbéremelések ellenére a hazai lakbérek - a nyugati országok gyakorlatától eltérôen - a szocialista idớszak során mindvégig meglehetổsen alacsony szinten maradtak, $\mathrm{s}$ egy átlagos család havi jövedelmének mindössze 8-10\%-át tették ki. Ennek eredményeként a lakbérek formájában befolyt összeg még a minimálisan szükséges karbantartási és állagmegớrzési költségekre sem volt elegendô, ami egyébként az épületállomány mứszaki állapotának gyors hanyatlásában igen szembetứnôen megnyilvánult (2. ábra).

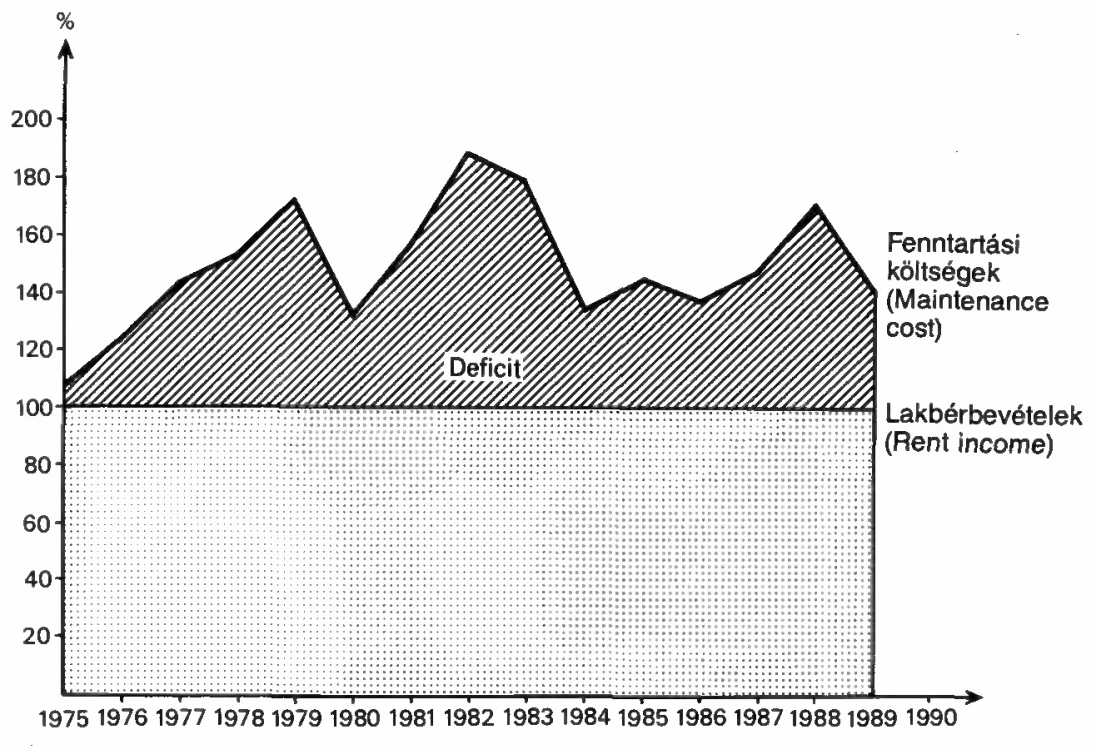

2. ÁBRA

A bérlakásszektor éves költségvetési mérlege Budapesten, 1975-1989

(Annual budget of social housing in Budapest between 1975-1989) 
Kovács Zoltán : A budapesti bérlakásszektor privatizációjának társadalmi- és városszerkezeti hatásai (Spatial aspects of the privatization of state housing in Budapest)

Tér és Társadalom 6. évf. 1992/3-4. 55-73. p.

60 Kovács Zoltán

TÉT $1992 \cdot 3-4$

A bérlakásállomány gazdasági csôdjében a merev, bürokratikus management is közrejátszott. A hatalmas vízfejjé növekedett ingatlankezelổ vállalatok képtelenek voltak a gondjaikra bízott több tízezer lakás gazdaságos üzemeltetését ellátni, és az idốszerưvé vált rekonstrukciós munkálatokat elvégezni ${ }^{5}$. Az amúgy is alacsony lakbérekból befolyt összeg jelentôs része, egyes becslések szerint a fele, pedig az ingatlankezelố vállalatok életbentartására, a gépezet müködtetésére folyt el.

Egyes vélemények szerint az ingatlankezelổ vállalatok pénzügyi helyzetének megrendülésében elsôdlegesen külsô okok játszottak szerepet, nevezetesen, hogy a lakbérek központilag, az elsổ gazdaságban kialakult értékviszonyoknak megfelelôen kerültek kialakításra, ugyanakkor a karbantartással kapcsolatos költségek egyre inkább a második gazdaság és ezzel együtt a piac befolyása alá kerülttek. Ezzel kapcsolatos számítások szerint az építkezési költségek az elmúlt 40 év során a tízszeresükre emelkedtek, mialatt a lakbérek ,,csupán” megnégyszerezôdtek ${ }^{6}$.

Az elmúlt négy évtized lakáspolitikája szociális szempontból sem volt különösebben sikeres. $\mathrm{Az}$ eredeti elképzelések szerint ugyanis az állam az arra rászoruló szegényebb rétegeket, ezen belül is a fiatal és több gyermekes családokat, volt hivatott olcsó állami lakással ellátni, míg a tehetôsebbeknek, valamint a falun élốknek maguknak kellett megfelelô hajlékról gondoskodni. Ezzel szemben a valóságban az történt, hogy a rendszer által kedvezményezett új, szocialista középosztály tagjai (munkahelyi vezetốk, értelmiségiek, párt és tanácsi alkalmazottak stb.) rendre elốnyben részesültek a lakáskiutalásoknál, s számukat jóval meghaladó arányban voltak reprezentálva az új lakótelepeken ${ }^{7}$. Az újonnan épült lakások érdemek alapján történổ szétosztása amellett, hogy ajándéktárgyat faragott az egyébként fogyasztási cikknek számító lakásból, jogtalanul elônyben is részesítette a társadalom egy privilegizált rétegét a többiek rovására.

Nem váltak valóra azok az elképzelések sem, hogy a szocializmusban, részint a lakáspolitika jóvoltából, a szegregáció fokozatosan megszünik. Pedig a szegregáció elleni harc, a társadalmi különbségek lakóhely szerinti összemosására tett kísérlet, a szocialista városfejlesztés egyik vezérmotívumává vált. Ezt célozta a különbözổ tulajdonformájú lakások térbeli kombinálása, az eltérõ társadalmi helyzetũ családok összeköltöztetése, s lényegében ehhez szolgáltatott funkcionális keretet a nagy homogén lakóegységek (t.i. lakótelepek) kialakítása is. A szocializmus kezdeti idôszakában ugyan valóban a szegregáció látványos csökkenésének lehettünk szemtanúi, ez azonban a 1970-es évek végétôl a visszájára fordult. A lakótelepek ekkorra sokat veszítettek korábbi népszerúségükbốl, s a középosztály tagjai szép számmal hagyták el korábbi lakhelyüket. Ez a folyamat jól nyomonkövethetô volt a magánlakásépítkezések hirtelen felfutásában, a káderdủlốk és más elit lakónegyedek szaporodásában. A szegregáció ilyetén elszabadulását a 80-as évek elejétốl a második gazdaság fokozatos megerõsödése, és a nyomában járó erốteljes vagyoni differenciálódás még tovább fokozta, s a 80 -as évtized vége felé már egyes nyugati városokat is megszégyenítố szegregációs különbségeket tapasztalhattunk a ,,szocialista" Budapesten $^{8}$. 
Kovács Zoltán : A budapesti bérlakásszektor privatizációjának társadalmi- és városszerkezeti hatásai (Spatial aspects of the privatization of state housing in Budapest)

Tér és Társadalom 6. évf. 1992/3-4. 55-73. p.

TÉT 1992-3-4

A budapesti bérlakásszektor

61

\section{A budapesti bérlakásállomány területi jellemzói}

Budapest lakásállományának még több mint 50\%-a van állami kézben, $\mathrm{s}$ ez a bérlakásállomány mind minôségi színvonalát, mind a bennük lakó bérlốk társadalmi státuszát tekintve területileg roppant heterogén képet fest.

A kb. 400 ezer állami lakás többsége (78\%-a) a pesti oldalon található, s arányuk különösen a belső kerületekben ér el kiugróan magas értékeket (95-97\%). Ezzel szemben világosan körvonalazható egy Rákosszentmihálytól-Nagytétényig húzódó városperemi öv, amelyben a bérlakások aránya 15-20\% alatt marad, s az itt található városnegyedeknek napjainkig sikerült megốrizniük túlnyomórészt kertvárosi jellegư beépítésüket (3. ábra).

Városszerkezeti összevetésben a tanácsi lakások két jelentôs térbeli tömörülése ismerhető fel Budapesten: 44\%-ukat a belváros, 33\%-ukat pedig a II. világháború óta épült lakótelepek koncentrálják. A fennmaradó $24 \%$ a belváros és a lakótelepi zóna közötti vegyes funkciójú, ún. átmeneti városövben oszlik szét. A belsô és a lakótelepi külsố bérlakásállományról, a privatizáció várható jelentôségét is szem elốtt tartva, külön is érdemes emlitést tenni. Jelen vizsgálataink során a belváros fogalmát a szokásosnál némileg tágabban értelmeztük. Lehatárolásában a lakások építésének kora, s az így fellelhetố mứszaki homogenitás játszotta az elsôdleges szerepet, s nem a hagyományos városökológia és funkcionális-morfológia szabta szempontok. Ezért a belsố városrészt Pesten a Dózsa György út - Mezô Imre út - Haller utca, Budán a Villányi út - Alkotás u. - Mártírok útja által körülhatárolt területtel azonosítottuk. Ez a terület a központi üzletnegyed ( $C B D-$ Central Business District) mellett az elsố lakóhelyi övezetet, sốt a második munkahelyi öv belsô, idôsebb részét is magába foglalja. Budapestnek ez a része már az I. világháború elổtt beépítésre került, s az itteni épületállomány igen jelentôs része a korábban is említett múlt század végi ,,városrobbanásos" folyamatnak volt az eredménye. Ez az a terület, amely jellegzetes négy-öt emeletes, belső udvaros házaival ma is meghatározza a fốváros arculatát. Az itteni bérlakásállomány mûszaki színvonalát a kerületi Ingatlankezelô Vállalatok adatai alapján határoztuk meg. Alacsony komfortfokozatba soroltuk a hivatalosan , ,komfort nélküli'-nek, továbbá a ,,félkomfortos'-nak minôsített lakásokat. Az alacsony komfortfokozatú tanácsi lakások IKV körzetek szerinti arányát tekintve jelentôs különbségeket figyelhetünk meg az egyes belsố negyedek között (4. ábra).

A nagy különbségekre jellemzô, hogy amíg egyes belsô városrészek lakásállománya a minôségi mutatók tekintetében is állja a versenyt a város újabb negyedeivel szemben, s ổrzi hagyományosan magas társadalmi presztízsét (pl. a Várnegyed, Lipótváros), addig a Terézváros, Józsefvảros és Ferencváros Nagykörúton kívül esố részeiben az alacsony nívójú lakások aránya helyenként az 50\%-ot is meghaladja, s ezeken a területeken a gettósodás kézzelfogható jeleivel találkozhatunk. Ez nem csak azért jelent problémát, mert ezek az erốsen lepusztult negyedek a város legértékesebb belsô területeit foglalják el, hanem azért is, mert a faji alapon történố gettósodással számos nehezen orvosolható társadalmi feszültség is a felszínre kerül.

A bérlakások kereken egyharmada található a lakótelepeken, s mind a lakásállomány színvonalát, mind az itt élố népesség társadalmi és életkor szerinti tagozódását tekintve sokkal kiegyenlítettebb képet találunk, mint a belvárosban. Budapesten összesen 270 ezer lakás épült fel telepszerû́en az 1950-es évek eleje óta, s ezek 52\%-a van állami kézben. Az elsô kisebb lakótelepek az 1950-es évek elejétôl kezdve épültek, s ezek kis helyigénye még a beépített terü- 


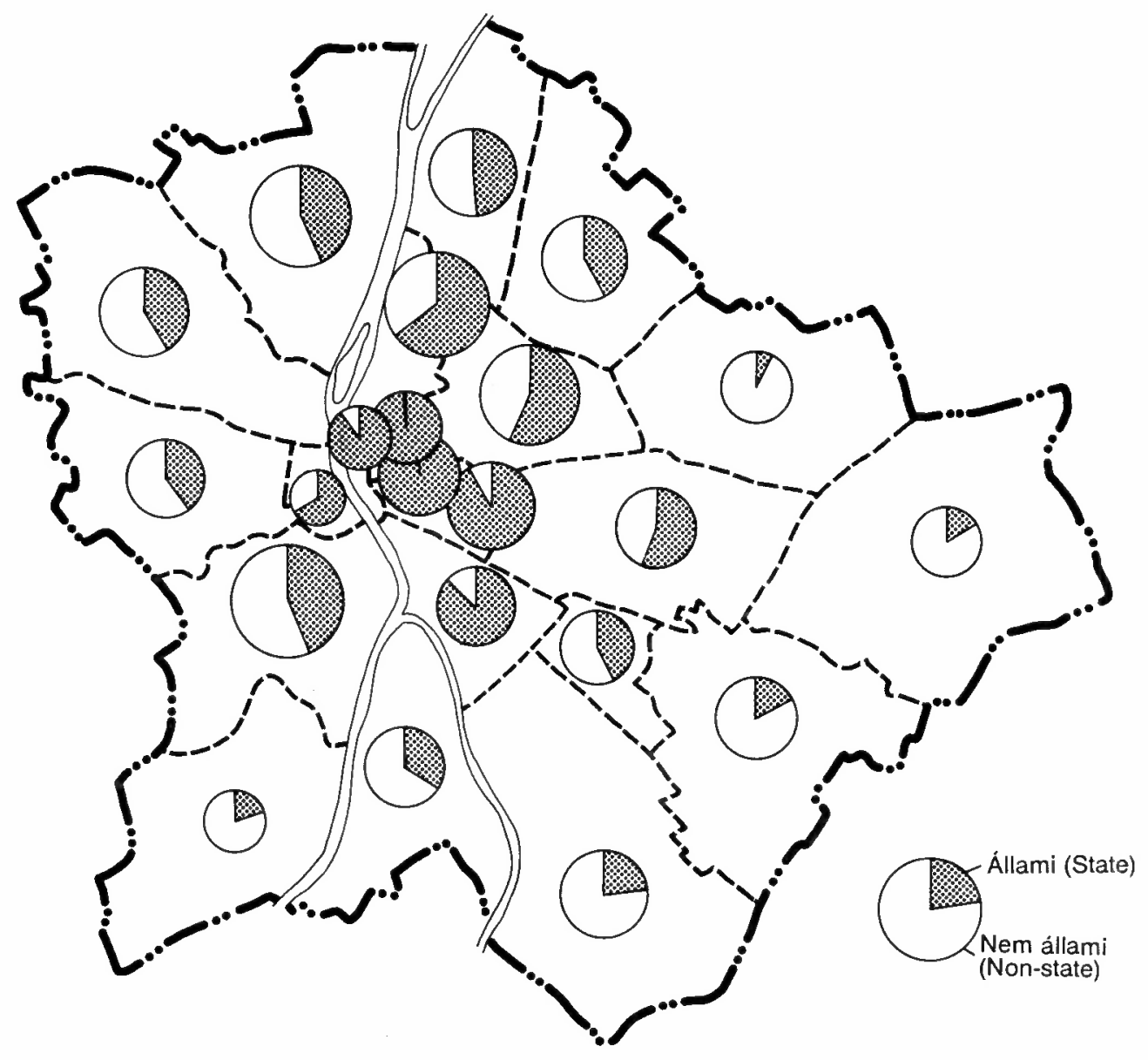

3. ÁBRA

A lakások tulajdon szerinti megoszlása Budapesten, 1988

(Dwellings by ownership in Budapest in 1988) 
Kovács Zoltán : A budapesti bérlakásszektor privatizációjának társadalmi- és városszerkezeti hatásai (Spatial aspects of the privatization of state housing in Budapest)

Tér és Társadalom 6. évf. 1992/3-4. 55-73. p.

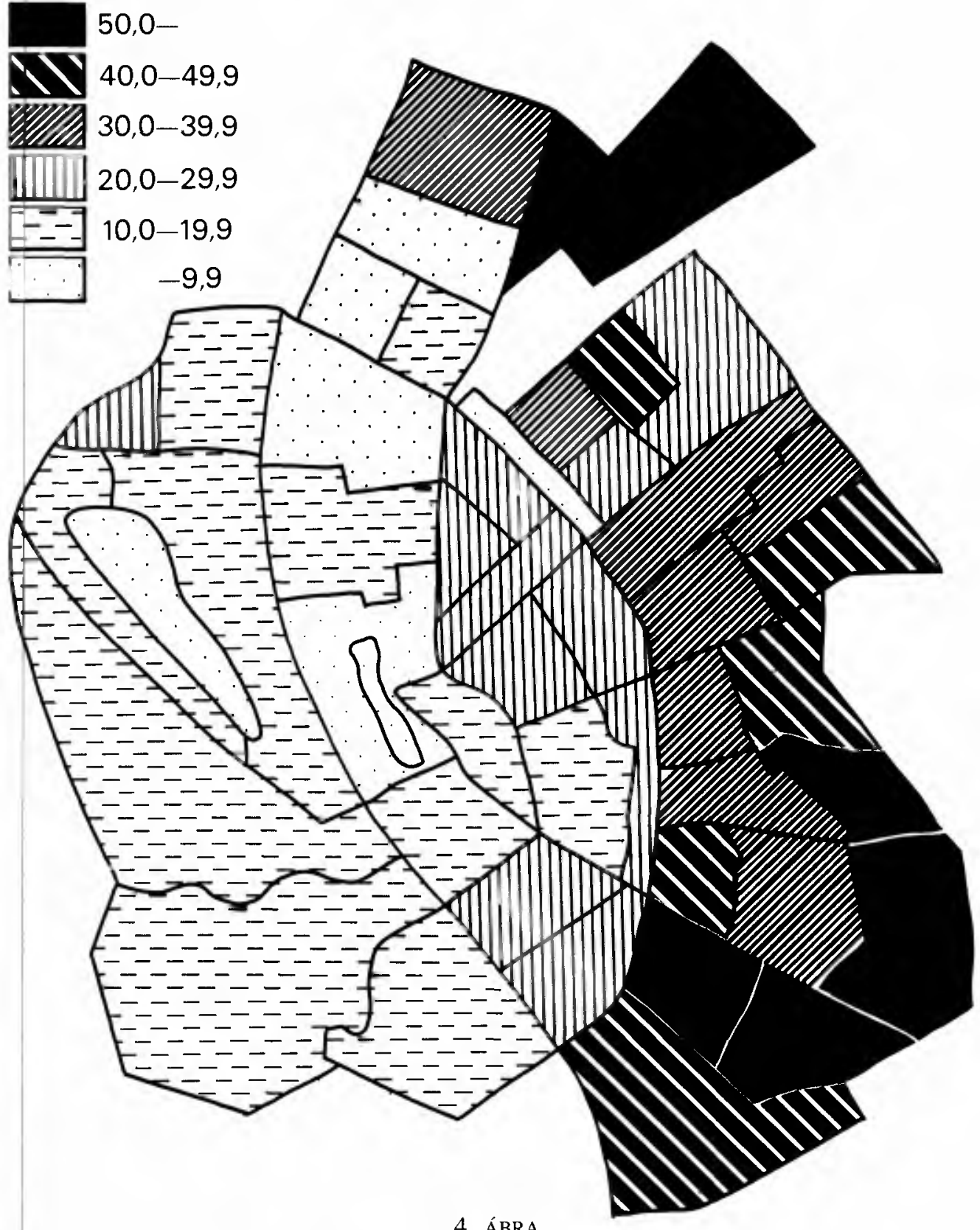

4. ÁBRA

A komfort-nélküli és fél-komfortos tanácsi lakások aránya Budapest belvárosában, 1988 (Ratio of substandard dwellings in Budapest inner-city in 1988) 
Kovács Zoltán : A budapesti bérlakásszektor privatizációjának társadalmi- és városszerkezeti hatásai (Spatial aspects of the privatization of state housing in Budapest)

Tér és Társadalom 6. évf. 1992/3-4. 55-73. p.

TÉT $1992 \cdot 3-4$

leten belül kielégíthetổ volt. Késốbb az elốregyártott technológia elterjedésével a lakótelepek mérete, és ezzel együtt térigénye, is nővekedni kezdett, ami arra kényszerítette a tervezóket, hogy az új lakótelepeknek a városszéli parlagterületeken találjanak helyet. Ez a város gyors fizikai expanziója mellett a korábban fennálló ökológiai szerkezet módosulásával is járt".

A lakótelepi lakások népszerüsége az 1980-as évek elejétôl rohamosan csökkent, ami a tartósan stagnáló ingatlanárakban is jól megmutatkozott. A lakótelepek szerepe egyre inkább leértékelốdött, s ma már sok fiatal család számára csupán átmeneti megoldásként jỏn szóba, a kezdeti lakásgondok orvoslására.

\section{A bérlakások privatizációjának területi jellemzói az ingatlanárak tükrében}

A privatizációval kapcsolatos szakirodalom két irányzatra különül aszerint, hogy a szerzốk a jelenséget csupán leegyszerüsítve, egy direkt gazdasági privatizációként értelmezik, mely során állami tulajdonban levố javak magántulajdonba mennek át, avagy a fogalmat szélesebb értelemben használják. A privatizációt szélesebb értelemben használó szerzók a magánszektornak az állami szféra rovására tett engedményeit is a privatizáció részének tekintik, ennél fogva a direkt denacionalizáció mellett több jelenséget is a privatizáció kategóriájába sorolnak ${ }^{10}$. Szerintủk a privatizációt szolgálja, ezért a privatizáció részének tekinthetố, a gazdasági liberalizáció éppúgy, mint az állami támogatások és szociális kiadások megkurtítása, a magánszektor által nyújtott szolgáltatások és javak fogyasztására tôrténổ ösztönzés stb. A lakásszektor vonatkozásában ilyen szempontból a privatizáció részének tekinthetô például a lakbéremelés, a kedvezményes lakossági építési hitelprogram, az építôipari vállalatok privatizácioja, illetve a magánépítkezések serkentése is.

Az állami lakások privatizációját Magyarországon elóször a 32./1969. sz. kormányrendelet szabályozta, amely mind a mai napig érvényben van. A jogi lehetổség ellenére azonban 1982. elốtt mindössze 2200 lakás cserélt gazdát, s a direkt privatizáció 1988-ig meglehetôsen alacsony szinten maradt (2. táblázat). Ebben az idôszakban a privatizációt az indirekt formák jellemezték, mint például a magánlakásépítések serkentése, vagy az állami lakásépítkezés elsorvasztása ${ }^{11}$.

A privatizáció csak 1988 végétôl 1989 elejétốl gyorsult fel igazán, amikor a kerületi tanácsok a törvény szabta kereteken belül szabadon rendelkezhettek a területükỏn található bérlakások felett. Ekkor kevesebb mint két év leforgása alatt kereken 100 ezer bérlakás került kijelölésre elidegenítés céljából, aminek részint a rendszerváltás, részint a privatizáció körüli közfelháborodás vetett véget, egy moratórium formájában. A privatizációra szánt lakások aránya területileg jelentốs eltéréseket mutat (5. abra). A budai oldal egyes magasabb presztízsú kerületeiben (II., XII, I. kerület) az eladásra kijelölt bérlakások köre 1990 végére meghaladta az 50\%-ot. Ugyanakkor a város kevésbé frekventált munkáskerületeiben (Kôbánya, Csepel, Újpest stb.) ez az arány 10\% alatt maradt, ami alól csupán Pesterzsébet és Kispest jelentett kivételt. 
Kovács Zoltán : A budapesti bérlakásszektor privatizációjának társadalmi- és városszerkezeti hatásai (Spatial aspects of the privatization of state housing in Budapest)

Tér és Társadalom 6. évf. 1992/3-4. 55-73. p.

\section{TÁBLÁZAT}

Az állami lakások évenkénti privatizációja Budapesten

(Annual privatization of state housing in Budapest)

\begin{tabular}{lccr}
\hline & 1. Vételi igény & $\begin{array}{c}\text { 2. Eladásra } \\
\text { kijelölve }\end{array}$ & 3. Eladott lakások \\
\hline 1982 elốtt & - & - & 2.200 \\
1982 & 361 & 161 & 83 \\
1983 & 1.804 & 964 & 224 \\
1984 & 2.811 & 3.103 & 350 \\
1985 & 1.999 & 2.578 & 494 \\
1986 & 1.735 & 1.044 & 711 \\
1987 & 2.619 & 1.913 & 933 \\
1988 & 13.853 & 6.160 & 1.854 \\
1989 & 44.221 & 28.131 & 6.232 \\
1990 & 74.545 & 71.792 & 26.709 \\
\hline 4. Összesen & 143.948 & 115.846 & 39.790 \\
\hline
\end{tabular}

1. Demand to purchase

2. Designated for sale

3. Sold flats

4. Total

A privatizáció területi intenzitása meglehetôsen szoros korrelációt mutat az 1990-ben regisztrălt budapesti ingatlanárak ${ }^{12}$ területi szóródásával ( 6 ábra). Ez az egybeesés közel sem véletlen, $\mathrm{s}$ az indokok alapvetớen a város társadalmi-ökológiai szerkezetére, valamint a lakásprivatizáció technikájára vezethetốk vissza. A tanácsi bérlakások privatizációja során ugyanis vételárnak a lakások forgalmi értékének $15 \%$-át tekintették, ha az elmúlt 15 évben teljes felújításban nem részesült az épület (a fôvárosban ez az általános). A vevổnek azonban nem kellett a teljes vételárat kifizetnie, elegendô volt annak $10 \%$-át egy összegben letennie, és a maradékot 35 évi részletben, 3\%-os kamattal fizethette.

Ha a vevố nem kívánt tartozni, hanem egy összegben akarta kifizetni a lakás árát, akkor a $10 \%$-on felüli részre $40 \%$ kedvezményt kapott. Ebben az esetben lakását a forgalmi érték 9,6\%-áért, tehermentesen megvásárolhatta. Ez alapján kiszámolható, hogy például egy 2 millió Ft forgalmi értéküre becsült bérlakást 192 ezer forint befizetésével tehermentesen meg lehetett văsárolni. Ezt a nagylelkử privatizációs elôirást még tovább enyhítette, hogy a kerületi tanácsoknak a valós piaci árakról csupán áttételes információik voltak, így a számítás alapját képezõ forgalmi érték is igen gyakran nagyságrendekkel eltért az ingatlan valós értékétốl. Ismertté vált olyan XII. kerületi eset, amikor egy 450 ezer forintért vásárolt (tehát 4,7 millióra becsült) ingatlant 50 milliórt adott tovább újdonsült tulajdonosa.

Mindezek ismeretében látható, hogy minél keđvezốbb fekvésú és minél értékesebb volt egy ingatlan, annál nagyobb haszonnal járt az adott feltételek szerint végrehajtott privatizációja a korábbi bérlớ (az új tulajdonos) számára. A bérlakások privatizációjának elsô fázisában ugyanakkor az értékesítésbôl származó egyszeri bevételek a tanácsok költségvetésében nem hoztak jelentôs növekedést, viszont sikerült a bérlakások legértékesebb részét áron alul elkótyavetyélni. 
Kovács Zoltán : A budapesti bérlakásszektor privatizációjának társadalmi- és városszerkezeti hatásai

(Spatial aspects of the privatization of state housing in Budapest)

Tér és Társadalom 6. évf. 1992/3-4. 55-73. p.

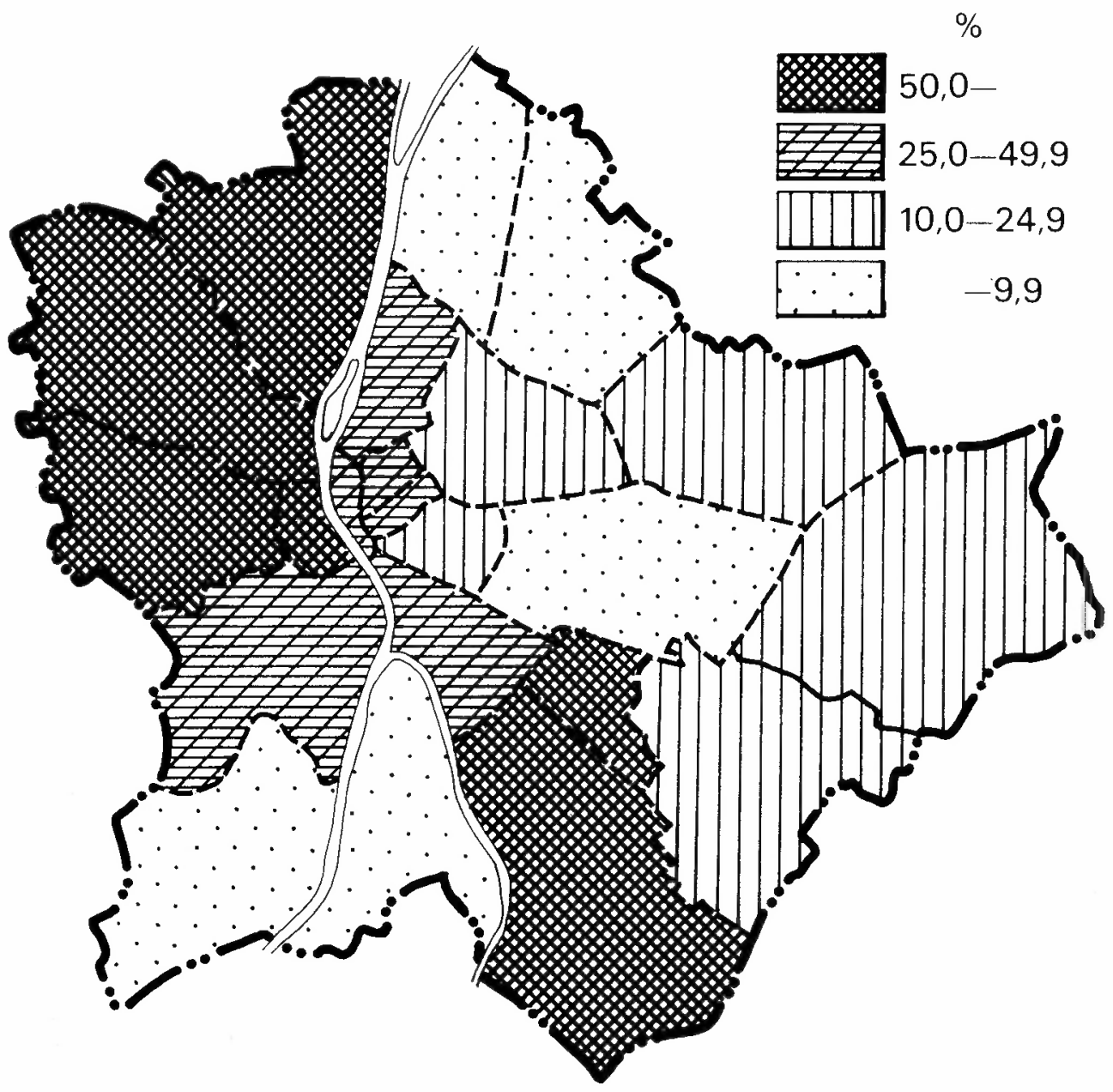

5. ÁBRA

A privatizálásra kijelölt állami lakások aránya, 1990

(The ratio of state dwellings designated to privatization, 1990) 
Kovács Zoltán : A budapesti bérlakásszektor privatizációjának társadalmi- és városszerkezeti hatásai (Spatial aspects of the privatization of state housing in Budapest)

Tér és Társadalom 6. évf. 1992/3-4. 55-73. $p$.

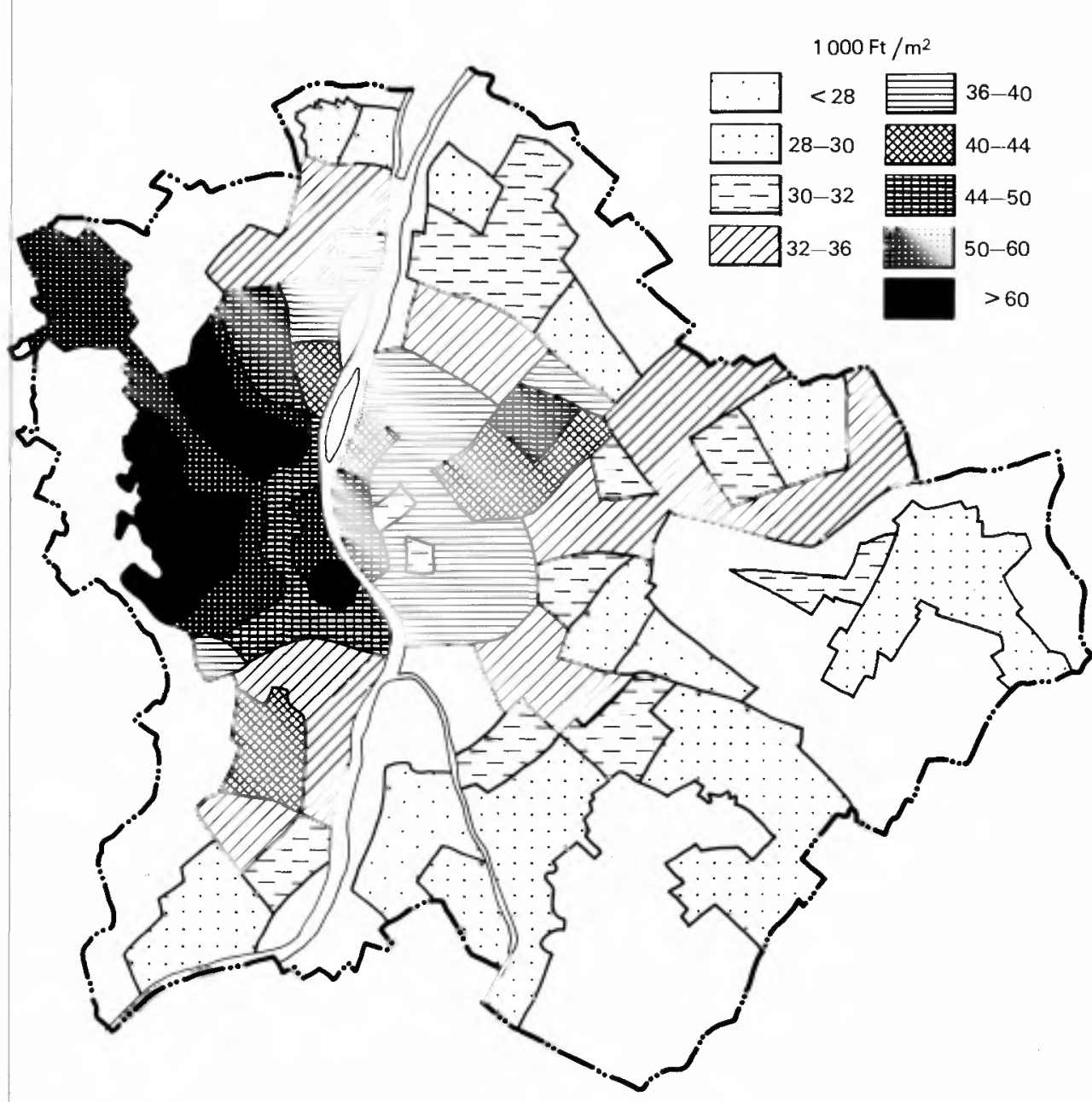

6. ÁBRA

A lakásárak területi szóródása Budapesten, 1990 (Apartment prices in Budapest, 1990) 
Kovács Zoltán : A budapesti bérlakásszektor privatizációjának társadalmi- és városszerkezeti hatásai (Spatial aspects of the privatization of state housing in Budapest)

Tér és Társadalom 6. évf. 1992/3-4. 55-73. p.

\section{A privatizáció társadalmi és városszerkezeti következményei}

A szociális lakásgazdálkodás nem kommunista találmány, s valamilyen formában régóta létezik a fejlett világ legtöbb országában. Még csak azt sem mondhatjuk, hogy az állami lakások aránya Budapesten túlzott lenne, hiszen 50\%-ot megközelítô, vagy azt meghaladó (tehát jelentổs) bérlakásszektor található számos nyugat-európai nagyvárosban is (pl. Glasgow, Manchester, Berlin). Véleményünk szerint a szociális bérlakáspolitika hazai csổdje nem annak eredeti elképzeléseiben, hanem pártállami megvalósításában győkerezik.

A lakásprivatizáció további szükségessége elvitathatatlan, de ennek nyíltan, szigorúan piaci feltételek mellett kell történnie. Az $1989 / 90$ során sebtiben végrehajtott elsố privatizációs szakasz ugyanis a tények ismeretében inkább ajándékozási aktusnak tekinthetố, semmint privatizációnak. Olyan ajándékozásnak, mely során a megajándékozottak immár másodszor részesültek az ajándékozó (voltaképp az állam) kegyeiben. Az elsổ akkor történt, amikor az állam a bérlốnek utalta ki a lakást, gyakorlatilag ingyen, s éveken át megkímélte ốt az alacsony lakbérpolitikával a társadalom nagyobbik felére nehezedổ súlyos kiadásoktól. Most másodszor is ajándékozott az állam, lehetổvé téve a drága, nagy értékú ingatlanok áron alul történố megvételét. Erre még az sem mentség, hogy a helyi önkormányzatok rá voltak szorulva a privatizációból befolyó összegekre, és az állam is szabadulni akart a bérlakásállomány fenntartásának terheitól.

A jơvớben privatizálásra kerüló lakásoknál figyelembe kell venni nem csak a lakás múszaki állapotát, hanem annak földrajzi elhelyezkedését is. A Sváb-hegy és Soroksár közti különbségeket szükségtelen e helyütt hangsúlyozni. Ahol ez indokolt, a lakás ára a forgalmi érték akár $50-60 \%$-át is elérhetné, s természetesen a forgalmi értékek megállapításánál is a reális piaci adatokra kell támaszkodni. A privatizáció mellett továbbra is szükséges azonban, hogy az állam, a helyi önkormányzatokon keresztül, szociális lakással segítsen az arra rászorulóknak. Ma még nehéz megmondani, hogy mi lenne az optimális arány, de Budapesten a lakásállomány 15-20\%-át mindenképpen indokolt lenne szociális lakás céljából visszatartani. A szociális célú lakások jövớbeni koncentrációja elsôsorban a lakótelepi övezet lesz, amely a jövốben várhatóan tovább veszít amúgy is rohamosan csỏkkenố népszerüségébốl.

A lakásprivatizáció amellett, hogy hangsúlyozott jelentôséggel bír a társadalom egyre gyorsuló vagyoni differenciálódásában, meghatározza Budapest egész további fejlôdését is. A privatizáció révén egyszerre nagy mennyiségứ lakás kerül be a lakáspiacra, ami amellett, hogy élénkíti a ma még meglehetôsen alacsony lakásmobilitást, egész városnegyedeket szabadít fel az állami tulajdonlás okozta fejlôdési kényszerpálya alól. A magánszféra megerôsödése és a tốkés ingatlanforgalom ismételt meghonosodása a föld és ingatlanértékek tisztázódásával jár együtt, ami a város jelenlegi ökológiai szerkezetét is rövid idố alatt újrarajzolja majd. Ez távlatilag annyit jelent, hogy a belváros és általában a központhoz közelebb fekvớ negyedek felértékelơdnek, s egy átmeneti periódus során, tisztán állami tulajdonból - a középületek és közhivatalok kivételével - magántulajdonba mennek át. A belváros felértékelódésében nagy szerepet játszik az üzleti élet, a külföldi cégek és vegyesvállalatok részéról megnyilvánuló kitüntetett figyelem. Budapest 1918. elốtti regionális üzleti szerepköre, amely kiterjedt a Kárpát-medencén túl a Balkán és az Orosz Birodalom egyes részeire is, ma szemmel láthatóan újjászületổben van. Erre utal egyebek mellett a multinacionális cégek irodanyitási láza is. Márpedig a jelenlegi súlyos 
Kovács Zoltán : A budapesti bérlakásszektor privatizációjának társadalmi- és városszerkezeti hatásai (Spatial aspects of the privatization of state housing in Budapest)

Tér és Társadalom 6. évf. 1992/3-4. 55-73. p.

TÉT 1992-3-4

A budapesti bérlakásszektor

irodahiány folytán Budapest belvárosa ma még alkalmatlan arra, hogy kiszolgálja a világcégek érdeklôdésébe került ország igényeit ${ }^{13}$. Nehéz bármit is megjósolni, de az már most látható, hogy a belváros a privatizáció révén funkcionális konverzió elé néz, ami a lakófunkció zsugorodásával, az üzleti, idegenforgalmi és szolgáltató funkció robbanásszerú fejlôdésével, vagyis a city-képzõdés felgyorsulásával jár ${ }^{14}$.

A city-képzôdési folyamat - a lakónépesség látványos csökkenése mellett - várhatóan a helyi társadalom kicserélổésével, egy fiatal, magasabb társadalmi státusú népesség megjelenésével, közismert nevén a dzsentrifikációval jár. A dzsentrifikációról az 1970-es évek közepétớl jelentek meg az elsố nagyobb lélegzetứ tanulmányok a fejlett országokban, fôleg geográfusok és városszociológusok tollából ${ }^{15}$.

Maga a folyamat a leromlásnak indult slumosodó belvárosi részek, elhagyott ipar- és raktárnegyedek társadalmi és fizikai revitalizációját jelenti, vagyis azt a folyamatot, amikor az említett városnegyedeket megszállja a posztfordi gazdaság sikerein megizmosodott újgazdag értelmiségi, -menedzseri (yuppie) ${ }^{16}$ réteg. A dzsentrifikáció tehát valójában a lakóhelyi szegregáció egyik módja, melynek során új, dinamikus társadalmi réteg nyomul be egy korábban elhagyott vagy alacsonyabb státusú réteg által lakott területre, és fokozatosan kiszorítja onnan az eredeti lakosságot. Ehhez kényszerítố eszközül a lakás- és ingatlanpiac szolgál, rohamosan növekvô, a helybeliek számára elóbb vagy utóbb megfizethetetlen áraival.

A dzsentrifikáció budapesti megjelenésével kapcsolatosan ma még meglehetơsen szkeptikus hangvétel jellemzi a szakmai közvéleményt, bár egyféle ,,szocialista” dzsentrifikáció kimutatására már ezt megelớzóen is történtek kísérletek ${ }^{17}$. Annyi bizonyos, hogy a jelenség mưssakimateriális háttere, a nagy kiterjedésư, potenciálisan értékes, ugyanakkor rendkívül lepusztult belvárosi lakónegyedek képében már ma is rendelkezésre áll. A tôkeerốs, saját miliôre vágyó középosztály ugyan ma még csak csíráiban létezik, de ha a polgárosodás hazai ütemét, és a jobbközép kabinet ez irányú intencióit figyelembe vesszük, minden bizonnyal rövidesen nálunk is megjelenik a fehér-galléros dzsentri réteg.

A belváros szerepének átértékelôdése, illetve a meginduló társadalmi és fizikai regeneráció a korábbi szocialista városökológiai modellt is alaposan átformálja. Mint arra Szelényi rámutatott, a magyar és általában a kelet-európai városok ökológiai szerkezete az elmúlt négy évtized szocialista várostervezése nyomán eltérớ jegyeket mutat a kontinens nyugati felén tapasztalt irányoktól. A nyugat-európai városokban, miként nálunk is, a II. világháború elốtt a lakosság társadalmi státusa a belvárostól a városok széle felé haladva fokozatosan csökkent. Ezzel szemben a szocialista városokban a társadalmi struktúrát jelzố görbe $\mathrm{V}$ betũhöz vált hasonlatossá, ami azt jelentette, hogy a városközpont hagyományosan magas társadalmi státusa az elsổ lakóhelyi övben (Budapesten hozzávetôleg a Kis- és Nagykörút között) hirtelen lecsökkent, hogy azután a város szélei felé haladva, az új lakótelepek gyưrũjében, ismét meredeken emelkedjen $^{18}$. A lakásprivatizáció és a nyomában járó belsô migráció a fentiekben leírt ökológiai görbét visszájára fordítja, s a jövơ évszázad elegáns negyedeit a belvárosban, míg slum negyedeit minden bizonnyal a lakótelep zónában kell keresnünk. Budapest a bérlakásszektor privatizációja révén fejlódésének egy újabb fordulópontjához érkezett. A szocialista várostervezés kreálta városmodell ideiglenes jellegư volt, $\mathrm{s}$ ha a jelenleg tapasztalható társadalmi-gazdasági folyamatok a továbbiakban is zavartalanul érvényesülhetnek, négy évtized kitérớ után a városfejlôdés és városgazdálkodás terén is visszatérhetünk az európai normákhoz. 


\section{Jegyzetek}

1 Lsd. Hegedūs J. - Tosics I. (1981), Kovács Z. (1990b).

2 Csupán egyetlen évtizedben, 1890 és 1900 között, 45\%-kal gyarapodott Budapest népessége, s az európai városok népességi rangsorában 1870 és 1900 között a tizenhetedik helyrốl a nyolcadik helyre lépett elôre. A hirtelen növekedésnek indult metropolis tervszerú fejlesztéséért az 1870-ben létrehozott Közmunkák Tanácsa felelt, melynek jótékony hatása napjainkig érezhetổ. Errốl a korról számol be izgalmas könyvében John Lukács (1991).

3 Lsd. Hegedũs J. (1987).

4 A lakásfinanszírozási rendszer az infláció erốsödése miatt elviselhetetlen terheket rótt a költségvetésre. A költségvetés 1986-1989 között duplájára nōvelte lakáscélú kiadásait, s 1989-ben már 80 milliárd Ft-ot fordított kedvezményes lakásépítési hitelekre, valamint a lakbérek illetve a tanácsi lakások fenntartási kiadásainak támogatására. Ebból 11 milliárd Ft volt az effektív lakbértámogatás, ami annyit jelentett, hogy az álam a bérlakások lakbérének minden forintjához 1.50 Ft-ot tett hozzá.

5 Becslések szerint Budapesten 107000 tanácsi bérlakás szorul sürgôsen nagyobb felújításra.

6 Lsd. Hegedû́s J. (1989).

7 Lsd. Szelényi I. (1990).

8 Lsd. Ladányi J. (1989).

9 Lsd. Szelényi I. (1990).

10 Lsd. Duke V., Edgell S. (1983).

11 Lsd. Tosics I. (1987).

12 A térkép elkészítésénél egy már korábban is alkalmazott módszer szerint, az Expressz hirdetési újság ingatlan rovatában kiválasztott, és telefonon lekérdezett ingatlanárakat vettük figyelembe. Az adatfelvételezést elốször 1988 elején végeztük el, majd 1990 tavaszán megismételtük. Lsd. Kovács Z. (1989).

13 Ma még sokakat elriasztanak a Béccsel és Párizzsal vetélkedô, rendkívül magas budapesti irodabérleti díjak (minimum 25 \$ négyzetméterenként havonta).

14 Ebben a folyamatban nagy elốrelépést jelent majd a privatizáció következô szintje, a külföldiek ingatlanszerzésének küszöbön álló liberalizációja.

is Lsd. Jackson, P. (1985), Short, J.R. (1989), Smith, N. (1982), Smith, N., Williams, P. (szerk.) (1986).

16. Az angol-amerikai szlengben a yuppie, , young upwardly mobile professional person" rövidítéséból származik, s a társadalmi ranglétrán gyorsan fölfelé törổ, fehérgalláros fiatalokra utal. A yuppie-k többsége magasan iskolázott, s jelentós részük az üzleti és pénzügyi szolgáltatásokban, az információs szektorban, a bank-, hitel-, és biztosító életben, vagy a divatiparban dolgozik. A yuppie-k nemcsak lakóhely, de életmód, divat, nyelvhasználat, egyszóval életstílus tekintetében is elkülönülnek a társadalom többi tagjától, jóllehet önmagában véve nem egy homogén társadalmi csoportról van szó. A társadalom egészéhez képest viszonylag felülreprezentáltak körükben a férfiak, a bankmenedzserek, a mũvészek, a homoszexuálisok, a környezetvédốk és a vegetáriánusok stb. Ennek megfelelốen egy dzsentrisedett területen belül különféle csoportjaik térbelileg elkülönülve, sajátos szimbólumaik révén, jól megkülönböztethetố társadalmi miliốt hoznak létre. P1.: karrier-orientált miliổ, technokrata-liberális milliố, alternatív baloldali milliổ stb. Mindez érthetôen rányomja bélyegét a városképre is. Arra, hogy mely csoportjuk adott újra életet egy városrésznek, könnyen rájöhetünk az épületek külsô festése̋̉bốl, díszítésérốl, az utcákon parkoló kocsik típusából, az alternatív élelmiszer üzletek vagy a pénzkiadó automaták jellegébốl és gyakoriságából. Ebben a témakörben lásd még Kovács Z. (1990a).

17 Lsd. Cséfalvay Z. - Pomázi I. (1990).

18 Részletesen lsd. Szelényi I. (1990).

\section{Irodalom}

Cséfalvay Z. - Pomázi I. (1990) Az irányított dzsentrifikáció egy budapesti rehabilitációs program példáján, Területi Kutatások, 9.

Duke, V. és Edgell, S. (1983) Public expenditure cuts in Britain and consumption sectoral cleavages, International Journal of Urban and Regional Research.

Hegedús J. - Tosics I. (1981) Lakáspiac és lakásrendsžr, Valóság, 7.

Hegedús J. (1987) Reconsidering the roles of the state and the market in socialist housing systems, International Journal of Urban and Regional Research, Vol. 11, No. 1.

Hegedüs J. (1989) The state-rental sector in the inner part of the socialist city, A , Social Theory and the Production of the Built Environment" c. konferencia anyaga, Noszvaj. 
Kovács Zoltán : A budapesti bérlakásszektor privatizációjának társadalmi- és városszerkezeti hatásai (Spatial aspects of the privatization of state housing in Budapest)

Tér és Társadalom 6. évf. 1992/3-4. 55-73. p.

Jackson, P. (1985) Neighbourhood change in New York: the loft conversion process. - Tijdschrift voor Econ. en Soc. Geografie, 76.3.

Kovács Z. (1989) A lakásmobilitás társadalomföldrajzi vizsgálata Budapest példáján, Földrajzi Értesító, $1-2$.

Kovács Z. (1990a) A posztfordizmus hatása a nagyvárosok társadalmára, Területi Kutatások, 9.

Kovács Z. (1990b) Rich and poor in th : Budapest housing market. In: C.M. Hann (szerk.). Market economy and civil society in Hungary, (London, Frank Cass).

Ley, D. (1986) Alternative explanations for inner-city gentrification: a Canadian assessment, Annals of the Association of American Geographers, 76.4.

Lukács J. (1991): Budapest, 1990 - A város és kultúrája, Budapest, Európa Kiadó.

Ladányi J. (1989): Changing patterns of residential segregation in Budapest, International Journal of Urban and Regional Research.

Short, J. R. (1989): Yuppies, yuffies and the new urban order, Transactions of the Institute of British Geographers, 14. Smith, N. (1982) Gentrification and uneven development, Economic Geography, 58.

Smith, N. - Williams, P. (szerk.) (1986): Gentrification of the city, London.

Szelényi I. (1990) Városi társadalmi egyenlótlenségek, Akadémiai Kiadó, Budapest.

Tosics I. (1987) Privatization in housing policy: the case of the western countries and that of Hungary, International Journal of Urban and Regional Research, 11, 1.

\section{SPATIAL ASPECTS OF THE PRIVATIZATION OF STATE HOUSING IN BUDAPEST}

\section{ZOLTÁN KOVÁCS}

A common feature of the emerging East-European democracies is the introduction of market economy. Although the social and economic development of these countries have had significant differences in the past, each of them considers privatization as the key element of the current economic and social transformation. Beside the privatization of the productive sector, which goes on rapidly now, great attention is paid to the privatization of housing, which influences the living conditions in a more direct way. The aim of this paper is to provide an overview about the development of housing in Budapest, with special attention to the most recent phenomena and trends (i.e. privatization).

In the case of Budapest, we can identify three major periods in the history of housing construction and the physical expansion of the city. The first dynamic phase of urban development dates back in the last decades of the 19th century, when the present urban structure was shaped. Due to the rapid growth of population, housing construction was dominated mainly by speculative builders during this period. As a consequence, a huge private rented sector emerged in the inner part of the city, in the form of low-quality four- and five-storey tenement blocks which housed mainly low-income and - to a lesser extent - middle-class families.

The next extensive phase of urban development can be identified with the inter-war period when the main path of city development shifted outwards, to the peripheral zone. Housing construction in this period remained at a fairly low standard and only a relatively small part of the city, mainly on the Buda side, was built according to the new architectural principles of the 1920s and 1930s. A great deal of residential segregation persisted, even within the rapidly expanding industrial suburbs where great barriers could be observed, between elite workers 
Kovács Zoltán : A budapesti bérlakásszektor privatizációjának társadalmi- és városszerkezeti hatásai (Spatial aspects of the privatization of state housing in Budapest)

Tér és Társadalom 6. évf. 1992/3-4. 55-73. p.

who were provided with flats in workers' colonies set up by large-scale firms, and the mass of immigrant proletarians.

A radical shift came about in the housing policy at the end of the 1940 s, as part of the socialist transformation of the country. Capitalist production and distribution of housing, which were blamed for the previous inequalities, was effectively abolished. Instead, the state became the dominant force in urban housing, owning most of the housing stock indirectly through the local authorities. The new rent system, the nationalization of housing and the constant state intervention into the allocation process were to abolish the old forms of social inequality according to the principal goal of the Stalinist regime.

At the same time, housing construction and public infrastructure received very low priority in the economic plans of the 1950 s, the growth of the publicly rented sector could be attributed merely to nationalization at this time. Most of the property and dwellings of the old ruling class were confiscated by state and redistributed to members of the working class, party apparatus and armed forces. Due to excessive nationalization, the ratio of state sector rapidly grew up to 75 per cent within three years.

Large-scale state housing construction could only take place after 1956, when housing became a significant element of the living-standard policy of the Kádár regime. The new housing policy was embodied in the Fifteen Year National Housing Development Plan, which projected the construction of 250.000 new dwellings in Budapest alone (one million in the country as a whole) between 1960-1975. The following years saw a rapid increase in state housing expenditure and construction, a dynamism almost comparable to that of the late 19th century. The share of state dwellings in new housing rose from 50-55 per cent to 70-72 per cent by the mid-1970s.

As in the other state socialist countries, the housing industry in Hungary was based mainly on prefabricated technology and the newly established housing factories churned out a vast number of almost identical, two-roomed flats on large housing estates from the late 1960s.

Another important feature of this period, the one following the introduction of the New Economic Mechanism in 1968, was that a new housing policy was implemented which realized the role of the market and encouraged the private sector. The Fifteen Year National Housing Development Plan was eventually fulfilled, though only thanks to a 50 per cent overshoot in private construction.

In Budapest, direct privatization of housing was negligible before 1982, and it remained at a very low level until 1988. Yet, we could observe the relative growth of the weight of the private sphere from the early $1960 \mathrm{~s}$. This could be attributed, on the one hand, to the general liberalization of the economy which included the housing sector too, and, on the other hand, to the gradual state withdrawal from housing construction especially beginning with the late 1970 s. At the end of the 1970 s, the economy and the living standards began to stagnate, while the inflation rate increased. Hungary entered the longest economic crisis in its modern history, and consequently state housing construction began to fall.

In 1986, the state constructed 2.100 dwelling units in Budapest which was only 18 per cent of what it had been six years earlier. According to the latest information, only 100 new dwellings will be built by the state in 1991 in Budapest. As the large-scale state housing projects came to an end, most of the state-owned building companies also went bankrupt. 
Kovács Zoltán : A budapesti bérlakásszektor privatizációjának társadalmi- és városszerkezeti hatásai (Spatial aspects of the privatization of state housing in Budapest)

Tér és Társadalom 6. évf. 1992/3-4. 55-73. p.

TÉT 1992-3-4

A budapesti bérlakásszektor 73

Denationalization of state housing has been officially recognized and regulated in Hungary since 1969. The original decree of the government still operates and constitutes the legal basis for the present privatization. Despite the legal opportunity, Budapest city council had agreed to privatize only 2.200 dwelling units until 1982 . Between 1982 and 1989, this figure slowly grew and reached almost 16.000. Nevertheless, privatization could speed up only after 1989, when district councils became responsible for the local state housing stock again. Consequently, an additional 100 thousand state dwellings were designated for privatization in Budapest during the years 1989-1990. If the speed of privatization remains at this level, another 100 thousand state appartments will be desingnated for sale by the end of 1991. It means that the share of state-housing will be reduced to 25 per cent, and it is doubtfull at the moment, whether the process will stop at this point or will accellerate further.

The scale of the privatization of state housing shows remarkable differences within Budapest. For example, in the 2 nd and 12th districts, more than half of the state housing stock had already been privatized by the end of 1990 . These are the posh areas of Budapest with the highest prices per square meter. On the other hand, the pace of privatization remained quite modest (less than 10 per cent) in the traditional working-class areas such as Újpest, Kóbánya or Csepel.

In fact, local governments privatize state housing at extremely low prices. According to the law, a public flat can be sold to its renter for 15 per cent of the flat's market value if it has not been restored in the last 15 years. However, the new owner does not have to pay the total price in one sum, but only 10 per cent of it. The remaining part of the price can paid in monthly instalments over a maximum period of 35 years. Since the overwhelming majority of the council flats in Budapest have not been renovated during the last 15 years, most of the flats are being privatized according to these soft criteria.

If the appartment has gone through renovation within the last 15 years, the price is going to be 30 per cent of the current market price. However, given the lack of accurate information we found that local governments are not aware of real market prices and they calculate the appartment prices 10-20 per cent below the real value. Moreover, if the renter pays the calculated amount in one sum, he can get 40 per cent discount from the original price. It means that one can buy a flat in Budapest for 11 per cent of its market value.

We can easily understand, that the higher the values of the flat, the bigger profit can be made. Indeed, the wealthiest strata of the society, those who occupy the most expensive areas of the city (i.e. 2nd and 12th districts) were the first to realise this, thus the level of privatization is most advanced in these districts. It can be anticipated that social housing will shortly disappear in these parts of Budapest.

Obviously, this kind of privatization is very irritating for those who have not had access to state housing in the past. Since most of them are lower class people they feel that the same people are privileged by the new regime who were privileged by the old one, and enjoyed free accomodation as a "state gift" earlier. Privatization at this price means a second gift, an undeserved subsidy for them again. Local governments are in a difficult situation. The Budapest city council and the local district councils are ruled by liberals who are in opposition in the Parliament. The centre-right conservative government cut public expenditure, and left local authorities without any central subsidy. Therefore there is a great demand at local governments to make money by means of privatization.

Translated by Zoltán Kovács 